\title{
PENGARUH KARAKTERISTIK DIRI TERHADAP TINGKAT PENGETAHUAN IBU HAMIL TENTANG PENCEGAHAN PENULARAN CORONA VIRUS DISEASE 2019
}

\author{
Endah Mulyani ${ }^{1}$, Sulastri ${ }^{2}$, Zahrotul Hidayati ${ }^{3}$, Khaulah Mujahidah ${ }^{4}$ \\ 1,2,3,4 Program Studi Kebidanan, Fakultas Kesehatan Universitas Muhammadiyah Gresik \\ Email : endahmulyani@umg.ac.id
}

\section{ABSTRAK}

Dunia saat ini sedang dilanda pandemi penyakit baru yaitu Corona Virus Disease 2019 yang lebih dikenal dengan istilah COVID-19. Penyakit baru ini pada tahap ringan menyebabkan flu namun pada kasus yang lebih berat akan menjadi penyakit yang parah yaitu Severe Acute Respiratory Syndrome (SARS-COV). Ibu hamil adalah salah satu kelompok yang beresiko tinggi tertular. Penelitian ini bertujuan untuk melihat pengaruh karakteristik diri ibu (usia, pendidikan dan pekerjaan) terhadap tingkat pengetahuan ibu tentang pencegahan penularan COVID-19.

Penelitian ini menggunakkan jenis analitik dengan pendekatan cross sectional. Sampel penelitian ini adalah 46 ibu hamil di desa Leran kecamatan Manyar kabupaten Gresik. Beradasarkan hasil uji parsial regresi logistik berganda didapatkan hasil usia memiliki pengaruh terhadap pemahaman ibu sebesar 0,013 , pendidikan sebesar 0,000 dan pekerjaan 0,032 Sementara hasi uji simultan regresi logistik berganda didapatkan bahwa usia, pendidikan dan pekerjaan secara bersama - sama tidak berpengaruh terhadap tingkat pengetahuan ibu. Pengetahuan ibu adalah sesuatu yang perlu untuk diperhatikan karena usia yang matang, pendidikan yang tinggi dan pekerjaan yang mapan tidak menjamin seseorang untuk beperilaku sehat dengan selalu menjaga kebersihan dan pola makan agar kehamilan aman dan sehat.

Kata Kunci : Karakteristik diri, pengetahuan, ibu hamil, pencegahan, COVID-19

\section{ABSTRACT}

The world is currently being hit by a new disease pandemic, namely Corona Virus Disease 2019 which is better known as COVID-19. This new disease at a mild stage causes flu but in more severe cases it will become a severe disease, namely Severe Acute Respiratory Syndrome (SARS-CoV). Pregnant women are one of the groups at high risk of contracting them. This study aims to see the effect of maternal characteristics (age, education and occupation) on the level of maternal knowledge about preventing transmission of COVID-19.

This study used an analytic type with a cross sectional approach. The research sample was 46 pregnant women in Leran village, Manyar sub-district, Gresik district. The results showed that age, education and occupation influenced mother's understanding. However, the age of education and work do not have a simultaneous effect on the level of knowledge of the mother. Maternal knowledge is something that needs to be considered because mature age, high education and a well-established job do not guarantee a person to have a healthy behavior by always maintaining cleanliness and eating patterns so that pregnancy is safe and healthy

Keywords : Personal Characteristics, Knowledge, pregnant women, prevention, COVID-19.

\section{PENDAHULUAN}

Corona Virus Disease 2019 atau biasa disingkat dengan istilah COVID-19 merupakan penyakit menular yang disebabkan oleh virus SARS-COV2, secara umum virus ini akan menyebabkan penyakit dari hanya sebuah flu ringan hingga bisa menjadi penyakit yang lebih parah yaitu seperti Severe Acute Respiritory Syndrome (SARS-COV) dan Middle East Respiratory 
Endah Mulyani, Pengaruh Karakteristik Diri Terhadap Tingkat Pengetahuan Ibu Hamil Tentang Pencegahan Penularan Corona Virus Disease 2019

Syndreom (MERS-Cov) (Sari, Devi Pramita \& Sholihah, 2020).

Penyakit yang muncul akibat terinfeksi virus SARS-COV2 atau biasa dikenal dengan virus corona ini adalah penyakit jenis baru yang obat dan vaksinnya hingga saat ini belum ditemukan. Penyebaran COVID-19 sangat cepat dan luas hampir negara di seluruh dunia mengalami bencana non alam ini. Total penduduk dunia yang positif COVID-19 sampai dengan 16 Juli 2020 mencapai 13 juta orang dan angka ini terus bertambah (I. Satgas Covid-19, 2020)

Angka penyebaran di Indonesia naik setiap harinya sampai dengan tanggal 16 Juli 2020 total penduduk Indonesia yang positif COVID-19 sebanyak 81.668 orang. Tren peningkatan jumlah penduduk yang positif COVID-19 menjadikan negara Indonesia urutan ke 26 dari 216 negara di dunia(l. Satgas Covid-19, 2020). Luasnya wilayah dan tingginya jumlah yang tertular membuat kondisi ekonomi dan sosial negara Indonesia terpuruk.

Dampak lain yang tidak bisa dihiraukan adalah dampak psikologis atau kejiwaaan bagi seluruh penduduk Indonesia baik tua, muda, anak - anak, ibu hamil dan orang lanjut usia. Setiap hari di media televisi menunjukkan jumlah korban yang secara tidak langsung membuat penduduk ketakutan belum lagi pemberitaan sifat virus yang mudah sekali menyebar dan virus yang dapat bertahan hidup lama di benda (Nurislaminingsih, 2020)

Ketakutan dan kecemasan yang muncul pada penduduk disebabkan karena pengetahuan mereka yang berasal dari berbagai berita yang menyatakan bahwa virus ini sengat mudah menular, tidak ada obat dan vaksin yang dapat menyembuhkan bahkan mudah menyebabkan kematian bagi orang terinfeksi (Nurislaminingsih, 2020).

Kelompok masyarakat yang rawan tertular COVID-19 adalah ibu hamil. Perubahan yang terjadi pada tubuh ibu hamil baik secara anatomi maupun fisiologi karena adanya pertumbuhan dan perkembangan janin pada rahim ibu secara tidak langsung menyebabkan sistem pertahanan tubuh ibu menurun. Penurunan daya tahan tubuh ibu akibat proses menyesuaikan membuat ibu mudah terinfeksi berbagai mikroorganisme (Gultom, Lusiana \& Hutabarat, 2020).

Kesehatan ibu hamil merupakan salah indikator derajat kesehatan suatu negara. Pada kondisi normal angka morbiditas dan mortilitas ibu hamil di Indonesia masih tinggi ditambah dengan kondisi pandemi akan membuat angka ini terus naik. Pelaksanaan pelayanan kesehatan ibu hamil di era padnemi COVID-19 harus memperhatikan protokol kesehatan guna mencegah penularan virus corona pada ibu maupun tenaga kesehatan.

Berdasarkan data dari dinas kesehatan Gresik angka kejadian COVID-19 di kabupaten Gresik terus meningkat laporan terakhir pada tanggal 13 Juli 2020 sebanyak 1225 orang terkonfirmasi angka ini terus merangkak naik. Sementara untuk jumlah orang dengan status terkonfirmasi positif di kecamatan Manyar sebanyak 198 orang dan di desa Leran sebanyak 3 orang terkonfirmasi positif COVID-19 (G. Satgas Covid-19, 2020)

Berdasarkan data dari puskemas pembantu desa Leran saat ini terdapat 46 ibu yang sedang dalam kondisi hamil. Berdasarkan data $56,52 \%$ ibu hamil di desa Leran masuk dalam katagori ibu hamil dengan resiko tinggi. Pelayanan kesehatan pada ibu hamil adalah salah satu bentuk 
Endah Mulyani, Pengaruh Karakteristik Diri Terhadap Tingkat Pengetahuan Ibu Hamil Tentang Pencegahan Penularan Corona Virus Disease 2019

pelayanan kesehatan yang terkena dampak langsung oleh adanya pandemi COVID-19 hal ini karena ibu banyak yang merasa takut dan was - was dalam melakukan kunjungan yang bertujuan untuk memantau kesehatannya.

Pengetahuan ibu hamil mengenai COVID-19 perlu untuk diperhatikan karena ibu secara mandiri diharapkan untuk dapat melakukan antisipasi secara mandiri. Berdasarkan hasil survei awal yang dilakukan peneliti pada ibu hamil di desa Leran didapatkan $40 \%$ ibu hamil kurang mengetahuai tentang COVID-19 selama kehailan.

Hal ini perlu untuk diperhatikan karena pada kondisi normal kesehatan ibu hamil merupakan tantang tersendiri karena masih tingginya angka kematian dan kesakitan ditambah dengan adanya pandemi seperti ini. Banyak ibu hamil juga belum menerapkan pola hidup bersih dan sehat, kondisi ini akan menyebabkan meningkatnya morbiditas dan mortilitas pada ibu dan bayi baru lahir nantinya.

Berdasarkan uraian permasalahan diatas peneliti ingin melakukan pengkajian faktor apa saja yang mempengaruhi tingkat pengetahuan ibu hamil tentang COVID-19 sehingga nantinya diharapkan hasil dari penelitian dapat digunakan sebagai bahan acuan atau referensi dalam melakukan tindakan promotif dan preventif dalam upya pencegahan dan penanggulangan penularan COVID-19 pada ibu hamil di desa Leran kecamatan Manyar kabupaten Gresik

\section{METODE PENELITIAN}

Penelitian ini menggunakkan desain analitik dengan pendekatan cross sectional. Populasi dalam penelitian ini adalah ibu hamil yang ada di desa Leran kecamatan Manyar kabupaten Gresik yang berjumlah 46 orang. Penelitian ini dilaksanakan pada tanggal 14 Juli 2020 - 21 Juli 2020. Sampel diambul dengan teknik total sampling karena seluruh sampel digunakan menjadi sampe penelitian. Variabel independen pada penelitian ini adalah usia, pendidikan dan status bekerja ibu. Variabell dependennya adalah tingkat pengetahuan ibu mengenai pencegahan penularan COVID-19. Pada penelitian ini instrumen yang digunakan adalan kuisioner yang telah melalui ujia validitas dan reliabelitas. Data akan diolah dengan metode statistik dengan bantuan aplikasi SPSS, uji yang digunakan adalah regresi logistik berganda.

\section{HASIL DAN PEMBAHASAN}

Hasil penelitian dapat dilihat ditabel.

Tabel 1. Tingkat Pemahamahan ibu Hamil di desa Leran kecamatan Manyar Kabupaten Sidoarjo

\begin{tabular}{ccc}
\hline Variabel Independen & $\mathbf{n}$ & $\%$ \\
\hline Usia & & \\
$\leq 30$ tahun & 30 & 65,2 \\
$>30$ tahun & 16 & 34,8 \\
\hline Pendidikan & & \\
\hline Dasar & 15 & 32,6 \\
Lanjutan & 31 & 67,4 \\
\hline Pekerjaan & & \\
\hline
\end{tabular}


Endah Mulyani, Pengaruh Karakteristik Diri Terhadap Tingkat Pengetahuan Ibu Hamil Tentang Pencegahan Penularan Corona Virus Disease 2019

\begin{tabular}{ccc}
\hline Tidak Bekerja & 27 & 58,7 \\
Bekerja & 19 & 41,3 \\
\hline Pengetahuan & & \\
\hline Rendah & 18 & 39.1 \\
Tinggi & 28 & 60,9 \\
\hline Jumlah & $\mathbf{4 6}$ & $\mathbf{1 0 0}$
\end{tabular}

Tabel 2. Pengaruh variabel independen terhadap tingkat pengetahuan ibu hamil tentang pencegahan penularan dan pemeriksaan kehamilan pada masa pandemi COVID-19.

\begin{tabular}{|c|c|c|c|c|c|c|c|c|}
\hline \multirow{3}{*}{$\begin{array}{c}\text { Variabel } \\
\text { Independen }\end{array}$} & \multicolumn{4}{|c|}{ Tingkat Pengetahuan } & \multirow{2}{*}{\multicolumn{2}{|c|}{ Total }} & \multirow{3}{*}{ P-value } & \multirow{3}{*}{ OR } \\
\hline & \multicolumn{2}{|c|}{ Rendah } & \multicolumn{2}{|c|}{ Tinggi } & & & & \\
\hline & $\mathbf{F}$ & $\%$ & $\mathbf{F}$ & $\%$ & $f$ & $\%$ & & \\
\hline \multicolumn{9}{|l|}{ Usia } \\
\hline$\leq 30$ tahun & 16 & 88,9 & 14 & 50 & 30 & 65,2 & \multirow{2}{*}{0,013} & \multirow{2}{*}{8,000} \\
\hline$>30$ tahun & 2 & 11,1 & 14 & 50 & 16 & 34,8 & & \\
\hline \multicolumn{9}{|l|}{ Pendidikan } \\
\hline Dasar & 14 & 77,8 & 1 & 3,6 & 15 & 32,6 & \multirow[b]{2}{*}{0,000} & \multirow[b]{2}{*}{94,500} \\
\hline Lanjutan & 4 & 22,2 & 27 & 96,4 & 31 & 67,4 & & \\
\hline \multicolumn{9}{|l|}{ Pekerjaan } \\
\hline Tidak & 7 & 38,9 & 20 & 71,4 & 27 & 58,7 & \multirow{3}{*}{0,032} & \multirow{3}{*}{0,255} \\
\hline Bekerja & & & & & & & & \\
\hline Bekerja & 11 & 61,1 & 8 & 28,6 & 19 & 41,2 & & \\
\hline Jumlah & 18 & 100 & 28 & 100 & 46 & 100 & & \\
\hline
\end{tabular}

Tabel 3.Model Regeresi Logistik Berganda di desa Leran kecamatan Manyar Kabupaten Sidoarjo

\begin{tabular}{llll}
\hline Variabel Independen & Sig & OR & C1 95\% \\
\hline Usia ibu hamil & 0,217 & 6,782 & $0,325-141,689$ \\
\hline Pendidikan ibu hamil & 0,009 & 63,280 & $2,831-1414,475$ \\
\hline Pekerjaan ibu hamil & 0,952 & 0,929 & $0,085-10,107$ \\
\hline
\end{tabular}

Berdasarkan tabel 1 dapat kita lihat sebagian besar usia ibu hamil di desa Leran adalah $\leq 30$ tahun yaitu sebanyak 30 ibu $(65,2 \%)$. Sebagian besar ibu hamil memiliki pendidikan terkahir ditingkat lanjutan yaitu sebanyak 31 orang $(67,4 \%)$. Ibu hamil di desa Leran sebagian besar tidak bekerja yaitu sebanyak 27 orang $(58,7 \%)$. Tingkat pengetahuan ibu hamil tentang pencegahan penularan COVID-19 di desa Leran sebagian besar tinggi yaitu 28 ibu $(60,9 \%)$.Untuk melihat pengaruh karakterististik terhadap tingkat pemahaman ibu hamil tentang Pencegahan Penularan COVID-19 selama kehamilan dapat dilihat pada tabel dibawah ini:

Tabel 2 menunjukkan pengaruh karakteristik diri (usia, pendidikan dan pekerjaan) terhadap tingkat pengetahuan ibu hamil tentang pencegahan penularan 
Endah Mulyani, Pengaruh Karakteristik Diri Terhadap Tingkat Pengetahuan Ibu Hamil Tentang Pencegahan Penularan Corona Virus Disease 2019

COVID-19. Hampir seluruh ibu hamil yang memiliki pengetahuan rendah berusia $\leq 30$ tahun yaitu sebanyak 16 ibu $(88,9 \%)$ dari hasil uji statistik didapatkan $p$ value $=0,013$ yang berarti usia ibu berpengaruh terhadap tingkat pengetahuan ibu besar pengaruhnya bisa dilihat dari nilai $\mathrm{OR}=8$ yang berarti ibu yang berusia $>30$ tahun memiliki tingkat pengetahuan lebih baik sebesar $8 x$.

Berdasarkan tabel 2 juga bisa kita lihat hampir seluruh ibu yang memiliki tingkat pengetahuan yang baik adalah ibu dengan pendidikan lanjutan dari hasil uji statistik didapatkan $p$ value $=0,000$ yang artinya pendidikan ibu mempengaruhi tingkat pengetahuan ibu dengan nilai $\mathrm{OR}=94,5$ yang berarti ibu dengan pendidikan tinggi memiliki kesemptan 94,5x untuk memiliki tingkat pengetahuan yang lebih baik dari ibu dengan pendidikan rendah.

Sebagian besar ibu hamil yang tidak bekerja memiliki tingkat pengetahuan yang lebih tinggi yaitu sebanyak $20(71,4 \%)$ dan berdasarkan nilai uji statistik $p$ value $=0,032$ dengan $\mathrm{OR}=0,255$ hal ini menunjukkan peluang ibu yang tidak bekerja untuk memliki tingkat pengetahuan yang lebih baik daripada ibu yang tidak bekerja hanya 0,255 kali. Setelah melihat tabel 3 dapat disimpulan bahwa usia, pendidikan dan pekerjaan tidak mempengaruhi tingkat pengetahuan ibu hamil secara bersama - sama, namun dari ketiga variabel tersebut variabel pendidikan adalah variabel yang memiliki nilai $O R$ tertinggi yaitu sebesar 63, 28 kali hal ini menunjukkan pendidikan adalah variabel yang sangat mempengaruhi tingkat pengetahuan ibu hamil.

Penelitian ini menujukkan bahwa usia, pendidikan dan pekerjaan mempengaruhi tingkat pengetahuan ibu. Usia mempengaruhi tingkat kematangan seseorang dalam menerima dan mengolah informasi yang diberikan padanya. Tingkat pendidikan juga akan mempengaruhi tingkat penerimaan dan pengetahuan terhadap informasi yang diberikan. Semakin tinggi jenjang pendidikan seseorang akan semakin besar mempengaruhi cara mendapatkan informasi serta kemampuan dalam mengelola informasi guna untuk kepentingan dirinya.

Pada penelitian ini menunjukkan bahwa status pekerjaan ibu mempengaruhi tingkat pengetahuan ibu hal ini karena ibu yang bekerja memiliki banyak kesempatan untuk memperoleh informasi dari teman, atasan, tempat kerja sehingga sumber informasi tidak hanya pada satu media saja sehingga kemammpuan ibu dalam mengakses, menerima dan mengolah informasi yang diterima untuk kepentingan dirinya menjadi lebih baik dari ibu yang memilih untuk kerja dirumah atau menjadi ibu rumah tangga.

Karakteristik diri tidak menunjukkan adanya pengaruh secara bersama - sama terhadap tingkat pengetahuan ibu hal ini sesuai dengan penelitian (Wulandari, Anggun.et.al, 2020) yang menyatakan bahwa karakteristik diri (usia, pendidikan dan pekerjaan) tidak mempengaruhi tingkat pengetahuan, hal ini karena usia yang lebih matang, pendidikan yang lebih tinggi dan pekerjaan yang mapan tidak secara otomatis membuat orang tersebut memiliki kesadaran untuk berperilaku sehat.

Perilaku sehat dalam penelitian ini adalah mencegah penularan COVID-19 baik itu yang sesuai dengan protokol kesehatan yang diberikan oleh pemerintah atau dengan menerapkan pola hidup yang bersih dan sehat guna menjaga keselamatan dan kesehatan diri dan bayi yang ada dalam kandungannya. Namun pendidikan tetap 
Endah Mulyani, Pengaruh Karakteristik Diri Terhadap Tingkat Pengetahuan Ibu Hamil Tentang Pencegahan Penularan Corona Virus Disease 2019

menjadi salah satu faktor utama dalam tingkat pengetahuan seseorang hal ini karena seseroang dengan pendidikan yang tinggi dapat dengan mudah untuk menerima dan mengola informasi yang ada guna untuk kepentingan dirinya agar sehat dan aman selama masa pandemi COVID-19.

\section{KESIMPULAN}

Secara umum ibu hamil di desa Leran sebagain besar berusia $\geq 30$ tahun, memiliki pendidikan pada tingkat lanjut, serta sebagian besar ibu tidak bekerja. Tingkat pengetahuan ibu hamil mengenai cara mencegah penularan COVID-19 dalam

\section{DAFTAR PUSTAKA}

Gultom, Lusiana \& Hutabarat, J. (2020) Asuhan Kebidanan Kehamilan. Sidoarjo: Zifatama Jawara.

Nurislaminingsih, R. (2020a). Layanan Pengetahuan tentang COVID-19 di Lembaga Informasi. Jurnal IImu Perpustakaan Dan Informasi, 4(1), 1937.

Nurislaminingsih, R. (2020b). Layanan Pengetahuan tentang COVID019 di Lembaga Informasi. Jurnal IImu Perpustakaan Dan Informasi, 4(1), 1937.

Sari, Devi Pramita \& Sholihah, N. (2020). Hubungan antara Pengetahuan Masyarakat dengan Kepatuhan Penggunaan Masker sebagai Upaya Pencegahan Penyakit COVID-19 di Ngronggah. Jurnal IImiah Rekam Medis Dan Informatika Kesehatan, 10(1), 5255. katagori tinggi. Usia, pekerjaan dan pendidikan memiliki pengaruh yang signifikan terhadap tingkat pengetahuan ibu namun karakteritstik diri secara bersama - sama tidak memiliki pengaruh terhadap tingkat pengetahuan ibu hamil di desa Leran tentang pencegahan dan penularan COVID-19 selama kehamilan.

\section{SARAN}

Penelitian lebih lanjut dapat melihat dukungan keluarga, tokoh masyarakat dan tenaga kesehatan dengan pencegahan penularan COVID-19 pada ibu hamil.

Satgas Covid-19, G. (2020). Peta Persebaran COVID-19 di Gresik. Retrieved July 10, 2020, from https://satgascovid19.

gresikkab.go.id/peta-persebaran-covid19-di-kabupaten-gresik/

Satgas Covid-19, I. (2020). Infografis COVID-19 (16 Juli 2020). Retrieved July $16, \quad 2020, \quad$ from https://covid19.go.id/p/

berita/infografis-covid-19-16-juli-2020

Wulandari, Anggun; Rahma, Fauzi; Pujianti, Nita; Sari, Ayu Riana; Laily, Nur; Anggraini, Lia; Muddin, Farid Ilham; Ridwan, Agus Muhammad; Anhar, Vina Yuli; Azmiyanoor, Muhammad; Prasetio, D. B. (2020). Hubungan Karakteristik Individu dengan Pengetahuan tentang Pencegahan Coronavirus Disease 2019 pada Masyarakat di Kalimantan Selatan. Jurnal Kesehatan Masyarakat Indonesia, 15(1), 42-46. 